\title{
BENTUK STRATEGI ADAPTASI SOSIAL EKONOMI MASYARAKAT PETANI PASCA PEMBANGUNAN WADUK JATIGEDE
}

\author{
Annisa Nur Azizah, Dasim Budimansyah, Wahyu Eridiana \\ Universitas Pendidikan Indonesia \\ Jl. Dr.Setiabudi 229 Bandung 40154, Jawa Barat, Indonesia \\ Email: annisanurazizah8@gmail.com
}

\begin{abstract}
Abstrak Penelitian ini dilatarbelakangi oleh adanya peralihan lahan pertanian menjadi bendungan Jatigede yang menyebabkan masyarakat petani kehilangan lahan pertaniannya. Penelitian ini bertujuan untuk mengetahui bagaimana bentuk- bentuk strategi adaptasi sosial ekonomi yang dilakukan oleh masyarakat petani dalam mengstabilkan kondisi sosial ekonomi pasca pembangunan Waduk Jatigede. Penelitian ini menggunakan pendekatan kualitatif dan metode studi kasus. Pengumpulan data dilakukan dengan teknik observasi, wawancara, dan analisis dokumentasi. Informan penelitian ini terdiri dari informan pokok yaitu masyarakat petani yang terkena dampak dan informan pangkal yaitu Kepala Desa Tarunajaya. Hasil penelitian ini menunjukan bahwa strategi adaptasi sosial ekonomi yang dilakukan oleh OTD masyarakat petani terdiri dari strategi aktif, pasif dan jaringan sosial.
\end{abstract}

Kata kunci: masyarakat petani, pembangunan bendungan, sosial ekonomi, strategi adaptasi

\section{PENDAHULUAN}

Upaya memajukan kesejahteraan umum merupakan salah satu tujuan dari Negara Indonesia yang tercantum dalam Pembukaan UUD RI Tahun 1945. Pembangunan merupakan suatu cara yang ditempuh oleh pemerintah untuk memajukan kesejahteraan umum, baik di bidang sosial, ekonomi, budaya maupun politik. Salah satu proyek pembangunan yang sudah dilakukan di Indonesia adalah pembangunan Waduk Jatigede yang berlokasi di daerah Kabupaten Sumedang, Provinsi Jawa Barat. Tujuan dari Pembangunan Waduk Jatigede ini adalah mampu memberikan keuntungan serta dapat memberikan suatu manfaat, khususnya bagi pelestarian sumber daya air yang sangat berguna untuk meningkatkan kesejahteraan manusia. Sebelum dijadikan Waduk, kawasan Jatigede sendiri merupakan wilayah pemukiman dan lahan pertanian. Luas lahan sekitar 4946 hektar yang terdiri dari 5 kecamatan mencangkup tanah milik masyarakat ataupun tanah milik perhutani terkena dampak pembangunan Waduk Jatigede.

Pada saat proses pembangunannya, Waduk Jatigede ini sempat menimbulkan konflik sosial yang didasarkan dari ketidakadilan dan kerugian besar yang dialami oleh masyarakat yang terkena dampak pembangunan. Amila, M (2016) menyebutkan bahwa, konflik yang timbul dari pembangunan Waduk Jatigede tersebut menimbulkan konflik vertical dan konflik horizontal. Konflik vertical terjadi antara pemerintah dan masyarakat. Sedangkan, Konflik horizontal terjadi diantara OTD itu sendiri. Kedua konflik tersebut terjadi dikarenakan adanya perbedaan uang ganti rugi yang diberikan oleh pemerintah kepada masyarakat OTD. Sehingga, menimbulkan adanya ketidakadilan, kecemesan, ketidakberdayaan, keberakaran, dan keraguan yang semuanya mengarah pada permusuhan yang pada akhirnya menimbulkan konflik (Budimansyah,2015)

Dana kerahiman yang diberikan oleh pemerintahan saat ini, sangat tidak sebanding dengan hilangnya asset kepemilikan masyarakat OTD hingga tahun 2015, sehingga menimbulkan ketimpangan- ketimpangan sosial ekonomi pada masyarakat OTD Waduk Jatigede. Hal itu senada dengan pendapat Harun dan Ardiyanto (2012), bahwa pembangunan yang tidak benar-benar dilandasi prinsip pemerataan yang lebih baik di antara anggota masyarakat, dan tidak didasarkan pada akses yang lebih terbuka dan seimbang bagi peluang, serta elit-elit penguasa tidak secara murni dimotivasi dan mengabdi kepada prinsip- prinsip, pembangunan akan melahirkan ketimpanganketimpangan, ketidakadilan sosial dan ekonomi, penindasan terhadap hak-hak asasi manusia dan demokrasi serta bentuk-bentuk kebebasan lainnya. 
Desa Cibogo merupakan salah satu desa yang terkena dampak pembangunan Waduk Jatigede. Serta, merupakan desa yang terendam seluruhnya. Masyarakat Cibogo yang terkena dampak dari pembangunan Waduk Jatigede ini dengan terpaksa harus meninggalkan daerah tempat tinggalnya yang telah berpuluh-puluh tahun dijadikan tempat tinggal dan harus membangun tempat tinggal yang baru di daerah lain. Desa Tarunajaya merupakan salah satu daerah yang dijadikan sebagai tempat relokasi pemukiman baru bagi para masyarakat OTD dari Desa tersebut. Beralihnya tempat tinggal masyarakat Desa Cibogo ke daerah baru membuat masyarakat yang terkena dampak pembangunan Waduk mengalami penurunan kesejahteraan dalam hal sosial ekonomi. Sebagaimana apa yang dikatakan oleh Ruhi, Tabassum Khun (2012) dalam penelitiannya mengenai uraian Arundhati Roy dalam "The Greater Common Good" menjelaskan bahwa proses pembangunan Waduk-Waduk raksaksa di Negeri ini, maupun di belahan dunia manapun akan bermuara pada satu kesimpulan yang sama. Kesimpulan itu adalah bahwa pembangunan Waduk selalu membuat orang-orang yang tergusur mengalami kehancuran dalam hidupnya.

Bagi petani, lahan merupakan salah satu asset penting yang dimiliki petani untuk beraktifitas dalam mempertahankan keberlangsungan hidup. Hilangnya lahan garapan yang petani miliki, membuat mereka harus bisa mencari alternative lain untuk bisa mempertahankan hidupnya. Salah satu diantaranya yaitu dengan melakukan peralihan mata pencaharian. Ashley et al, 2003; Twigg, 2001 mengatakan bahwa, Perubahan mata pencaharian merupakan salah satu strategi untuk mencapai penghidupan yang berkelanjutan. Perubahan mata pencaharian merupakan salah satu reaksi masyarakat dalam menghadapi perubahan tren, musim, dan tekanan (Ratna, 2013). Sehingga peralihan mata pencaharian dari petani menjadi non petani merupakan salah satu upaya yang dilakukan untuk meningkatkan keberlanjutan sosial ekonomi di lingkungan geografis yang keadaannya berbeda dengan lingkungan sebelumnya. Masyarakat petani yang berpindah ke daerah Blok Pasirkandaga, pada umumnya berstatus sebagai petani lapisan bawah yang cenderung menerapkan strategy survival (Strategi bertahan hidup) untuk melanjutkan keberlangsungan hidupnya. Petani lapisan bawah, seperti buruh tani dalam melakukan strategi adaptasi sosial ekonomi hanya terfokus untuk memenuhi kebutuhan hidup sehari- hari saja.

Oleh karena itu, berpindahnya tempat tinggal masyarakat petani ke daerah lain, membuat mereka harus memulai kehidupan yang baru, serta merintis kegiatan ekonomi di tempat yang baru dengan berbagai cara dan strategi untuk melakukan keberlanjutan hidupnya di Blok Pasirkandanga, Desa Tarunajaya, Kec.Darmaraja. Tujuan dari penelitian ini adalah untuk mengetahui bagaimana bentukbentuk strategi adaptasi sosial ekonomi yang dilakukan oleh masyarakat petani di Blok Pasirkandaga, Desa Tarunajaya, Kec. Darmaraja pasca pembangunan Waduk Jatigede.

\section{METODE PENELITIAN}

Penelitian ini merupakan penelitian kualitatif dengan menggunakan metode studi kasus. Penelitian dilakukan di Blok Pasirkandaga, Desa Tarunajaya, Kec. Darmaraja, Kab. Sumedang. Informan penelitian terdiri dari 10 Orang, yaitu 9 orang masyarakat petani yang terkena dampak sebagai informan kunci, dan Kepala Desa Tarunajaya sebagai informan pendukung. Pihak-pihak tersebut mampu memberikan informasi yang dibutuhkan peneliti untuk menjawab permasalahan yang telah dirumuskan. Pemilihan partisipan untuk penelitian ini menggunakan purposive sampling dan snowball sampling. Hasil penelitian ini diperoleh melalui teknik observasi, wawancara, dan studi dokumentasi. Teknik analisis terdiri dari reduksi data, penyajian data dan verifikasi data (Milles \& Haberman, 2012). Data terakhir divalidasi dengan menggunakan teknik triangulasi sumber data dan teknik pengumpulan.

\section{HASIL DAN PEMBAHASAN 3.1 Strategi Adaptasi dengan Tujuan Menambah Pendapatan}

Berdasarkan hasil observasi dan wawancara, hilangnya lahan garapan masyarakat OTD yang bermata pencaharian sebagi petani, mengharuskan mereka mencari strategi alternative lain sebagai upaya dalam memperoleh pendapatan untuk memenuhi kebutuhan hidup sehari- hari pasca pembangunan Waduk Jatigede. Tindakan-tindakan yang dilakukan oleh masyarakat petani yang terkena dampak pembangunan sangat beragam. Tindakan pertama yaitu masih mempertahankan profesi sebagai petani pasca pembangunan Waduk Jatigede. Hal itu dilakukan oleh OTD masyarakat petani yang memiliki lahan garapan pengganti, baik lahan garapan di daerah lain ataupun lahan garapan baru yang berada di sekitar pinggiran Waduk Jatigede. 
Lahan baru tersebut merupakan lahan milik pemerintah sisa proyek pembangunan Waduk Jatigede yang kemudian dimanfaatkan oleh sebagian OTD masyarakat petani untuk dijadikan lahan persawahan baru. Sedangkan, OTD masyarakat petani yang tidak memiliki lahan garapan pengganti pasca pembangunan Waduk Jatigede ini, memilih untuk beralih mata pencaharian sebagai tindakan kedua, baik menjadi pencari ikan di Waduk Jatigede, pedagang opak, buruh bangunan, tukang ojeg, dsb. Pemilihan peralihan pekerjaan yang dilakukan ratarata merupakan pekerjaan sampingan mereka dulu, saat masih berprofesi sebagai petani.

Peralihan pekerjaan menjadi Nelayan Ikan di Waduk Jatigede, dilakukan oleh OTD masyarakat petani yang memiliki modal peralatan seperti, perahu/rakit bamboo yang dibuat sendiri, jaring ikan, dan peralatan ikan lainnya. Jenis ikan yang biasa didapatkan seperti ikan jaer, patin bahkan udang. Ikan-ikan yang di dapatkan biasanya dijual ke pengepul yang ada di daerah Cibugur, di jual ke pasar, atau tidak dikomsumsi sendiri. $1 \mathrm{~kg}$ ikan biasanya dijual dengan harga sekitar Rp. 15.000 Rp. 20.000/Kg. Selain, menjadi pencari ikan OTD masyarakat petani juga, ada yang melakukan peralihan pekerjaan menjadi pengusaha opak kecilkecilan. Perharinya opak yang dihasilkan sekitar 50 bungkus opak. Opak-opak tersebut, biasanya dijual ke pasar dengan harga Rp.5000-, per/ bungkus atau ke supermarket terdekat dengan harga Rp. 4500-, per/bungkus.

Peralihan pekerjaanpun dilakukan oleh OTD masyarakat petani dengan menjadi tukang ojeg dan buruh bangunan. OTD masyarakat petani yang memiliki aset modal berupa motor, akan menggunakannya sebagai alat untuk memenuhi kebutuhan hidup saat ini yaitu menjadi tukang ojeg. Biasanya tempat mangkal utama dilakukan di pasar Darmaraja. Selain digunakan sebagai modal untuk beralih profesi, ada juga yang menggunakan modal tersebut untuk dijadikan barang sewaan. Kendaraan bermotor yang dimiliki disewakan untuk dipakai mengojeg oleh orang lain. Sehingga, pemilik kendaraan tersebut hanya tinggal mendapatkan uang setoran saja. Hal berbeda dilakukan oleh OTD masyarakat petani lainnya yang melakukan peralihan pekerjaan menjadi kuli bangunan. Alasannya, dalam memilih pekerjaan itu, dikarenakan pekerjaan tersebut tidak membutuhkan modal produktif, modal finansial, serta modal keterampilan yang banyak. Hanya butuh tenaga yang besar saja pekerjaan menjadi kuli bangunan sudah bisa dilakukan. Pekerjaan menjadi buruh bangunan dilakukan ketika ada orang yang akan membangun rumah, pembangunan jalan desa, dan pembangunan fasilitas umum lainnya.
Pendapatan yang tidak menentu dan terbilang kecil, dari pekerjaan mereka saat ini. Membuat OTD masyarakat petani melakukan strategi lain untuk menambah pendapatan keluarga. Hal itu dilakukan dengan mendorong istri atau anak untuk ikut bekerja mencari nafkah. Pekerjaan yang dilakukan oleh istri OTD masyarakat petani diantaranya yaitu membuka warung kecil-kecilan dengan menjual sayuran dan makanan ringan di depan rumahnya, memproduksi opak, membantu menanam sayuran, ubi- ubian, serta buah-buahan untuk dijual. Tidak hanya istri peran anak yang sudah mampu bekerjapun menjadi suatu strategi untuk bisa mengstabilkan kondisi sosial ekonomi keluarga. Pekerjaan yang dilakukan oleh anak OTD masyarakat petani diantaranya yaitu ikut bekerja menjadi buruh tani, bekerja sebagai nelayan ikan di Waduk Jatigede, bekerja di pertokoan, dan ikut bekerja menjadi buruh bangunan.

\subsection{Strategi Adaptasi dengan Tujuan Mengurangi Biaya Pengeluaran}

Agar kebutuhan keluarga dapat terpenuhi dengan penghasilan yang terbilang pas-pasan. Masyarakat petani yang terkena dampak melakukan strategi penghematan. Strategi penghematan yang dilakukan yaitu dengan membeli bahan makanan seadanya serta mengolah bahan makanan dari hasil kebun. Hal itu dilakukan agar biaya yang dikeluarkan untuk makan tidak terlalu banyak. Lauk pauk yang biasa dikomsumsi terbilang sederhana, seperti sayuran, tahu, tempe, serta Ikan yang di dapat dari Waduk sebagai bahan makanan sehari-hari. Sedangkan, pengeluaran biaya non- makanan lebih kepada tidak membeli barang-barang elektronik maupun pakaian baru. Selain itu juga, lebih memanfaatkan kayu bakar sebagai bahan bakar memasak dibandingkan gas elfiji.

\subsection{Strategi Adaptasi dengan Tujuan Memanfaatkan Akses Sosial}

Mekipun masyarakat petani yang terkana dampak sudah melakukan berbagai macam strategi. Namun, kenyataannya strategi tersebut terkadang tidak bisa memenuhi kebutuhan hidup yang bersifat mendesak. Oleh karena itu, masyarakat petani memanfaatkan akses jaringan sosial. Pemanfaatan akses jaringan sosial biasanya dilakukan masyarakat ketika sedang membutuhkan keperluan yang bersifat mendesak. Akses jaringan sosial formal yang dimanfaatkan yaitu berupa bantuan dari pemerintah. Bantuan tersebut yaitu berupa dana pinjaman yang bersumber dari PNPM Desa, serta Beras Raskin 
yang biasa di dapatkan oleh masyarakat yang tergolong miskin. Sedangkan, Akses jaringan sosial lainnya yaitu berupa akses jaringan informal. Akses jaringan informal merupakan akses jaringan dengan cara meminjam uang ke kerabat terdekat atau mengutang ke warung untuk memenuhi kebutuhan sehari-harinya.

Berdasarkan hasil temuan penelitian, hilangnya mata pencaharian sebagai petani dan berpindah tempat tinggal ke daerah lain, mengharuskan masyarakat OTD yang berprofesi sebagai petani melakukan berbagai strategi adaptasi sosial ekonomi untuk bisa melanjutkan kehidupannya pasca Pembangunan Waduk Jatigede. Strategi adaptasi atau Coping Strategies dilakukan sebagai upaya untuk menyelesaikan berbagai macam masalah hidup yakni dengan memanfaatkan kemampuan segenap anggota keluarga dalam mengelola sumber daya yang dimiliki (Suharto, E, 2009). Sedangkan Scones (2001) mengatakan bahwa, "strategi adaptasi merupakan suatu kombinasi tindakan-tindakan yang dilakukan oleh rumah tangga untuk mencapai kesejahteraan menjadi lebih baik lagi. Kegiatan tersebut dilakukan dengan cara-cara memanfaatkan berbagai aset, pilihan aset untuk investasi serta bagaimana rumah tangga mempertahankan aset dan pendapatannya."

Berdasarkan hasil temuan penelitian, hilangnya mata pencaharian sebagai petani dan berpindah tempat tinggal ke daerah lain, mengharuskan masyarakat OTD yang berprofesi sebagai petani melakukan berbagai strategi adaptasi sosial ekonomi untuk bisa melanjutkan kehidupannya pasca Pembangunan Waduk Jatigede. Strategi adaptasi atau Coping Strategies dilakukan sebagai upaya untuk menyelesaikan berbagai macam masalah hidup yakni dengan memanfaatkan kemampuan segenap anggota keluarga dalam mengelola sumber daya yang dimiliki (Suharto, E, 2009). Sedangkan Scones (2001) mengatakan bahwa, "strategi adaptasi merupakan suatu kombinasi tindakan-tindakan yang dilakukan oleh rumah tangga untuk mencapai kesejahteraan menjadi lebih baik lagi. Kegiatan tersebut dilakukan dengan cara-cara memanfaatkan berbagai aset, pilihan aset untuk investasi serta bagaimana rumah tangga mempertahankan aset dan pendapatannya."

Ada beberapa strategi adaptasi sosial ekonomi yang dilakukan oleh OTD masyarakat petani untuk melakukan keberlanjutan hidup di daerah yang baru. Strategi adaptasi sosial ekonomi tersebut, diantaranya adalah sebagai berikut:

\subsection{Strategi Adaptasi Sosial Ekonomi Aktif}

Strategi adapatasi sosial ekonomi aktif merupakan sebuah strategi yang bertujuan untuk menambah pendapatan keluarga, dengan cara melakukan berbagai macam tindakan (Suharto, E, 2009). Strategi untuk memperoleh pendapatan yang dilakukan oleh OTD masyarakat petani, dilakukan dengan berbagai tindakan diantaranya yaitu tetap mempertahankan mata pencaharian sebagai petani, beralih mata pencaharian, melakukan migrasi sikuler, serta mendorong istri dan anak untuk ikut mencari nafkah. Aset modal yang digunakan oleh OTD masyarakat petani dalam melakukan strategi aktif diantaranya adalah (1) Aset produktif berupa Lahan pertanian, Waduk Jatigede, peralatan mencari ikan, peralatan memproduksi opak, peralatan bangunan, serta kendaraan motor. (2) Aset modal manusia berupa keterampilan dan kondisi kesehatan yang baik. (3) Aset tenaga kerja yaitu Anggota keluarga yang dapat ikut mencari nafkah, seperti istri dan anak. Pengelolaan aset modal yang dimiliki oleh OTD masyarakat petani tersebut dikaji berdasarkan kerangka analisis Moser yang disebut "The Aset Vulnerability Framework" yakni meliputi berbagai pengelolaan asset yang dapat digunakan untuk melakukan penyesuaian atau pengembangan strategi tertentu dalam mempertahankan kelangsungan hidup (Suharto,E, 2009). Di bawah ini akan dijelaskan lebih rinci mengenai strategi adaptasi sosial ekonomi aktif yang dilakukan oleh OTD masyarakat petani: Tetap berprofesi sebagai petani dengan memanfaatkan lahan pertanian di daerah lain dan lahan kosong di sekitar area Waduk Jatigede.

Blok Pasirkandaga merupakan salah satu daerah tujuan perpindahan penduduk OTD dari Desa Cibogo yang wilyahnya berada tepat di pinggiran Waduk Jatigede. Masyarakat petani yang terkena dampak di Blok Pasirkandaga banyak memanfaatkan lahan kosong yang berada tepat di pinggiran Waduk untuk membuka lahan persawahan dan perkebunan baru. Lahan kosong yang digunakan merupakan tanah sisa proyek Pembangunan Waduk Jatigede milik pemerintah. Lahan kosong tersebut dimanfaatkan oleh sebagian OTD berprofesi petani di untuk dijadikan area persawahan dan perkebunan. Selain menggarap sawah, sebagian OTD juga menanam berbagai jenis sayuran dan ubi-ubian. b. Melakukan Perpindahan Mata pencaharian dan Diversifikasi Pekerjaan

Berdasarkan hasil temuan penelitian, dalam melakukan keberlanjutan hidupnya di lingkungan yang baru pasca pembangunan Waduk Jatigede. Masyarakat petani yang terkena dampak memilih 
untuk melakukan perpindahan mata pencaharian. Hal itu senada dengan Ashley et al, 2003; Twigg, 2001 yang mengatakan bahwa, "peralihan mata pencaharian merupakan suatu reaksi masyarakat dalam menghadapi perubahan dengan tujuan untuk mencapai penghidupan yang berkelanjutan" (Ratna, 2013).

Perpindahan pekerjaan dari petani menjadi pencari ikan dilakukan dengan memanfaatkan Waduk sebagai sumber pendapatannya saat ini. Jurnal penelitian Sata, Winyoo, dkk (2008) dengan Judul Environment Changes of Lampao Dam Communities in Northeast Thailand membenarkan bahwa, beralih fungsi lahan pertanian menjadi sebuah Waduk, mengakibatkan adanya perubahan lingkungan, social, dan ekonomi. Sehingga, membuat para petani beralih mata pencaharian dari bertani menjadi pencari ikan di Waduk tersebut.

Selain, menjadi pencari ikan OTD masyarakat petani juga, ada yang melakukan peralihan pekerjaan menjadi tukang ojeg dan buruh bangunan. OTD masyarakat petani yang memiliki aset modal berupa motor, akan menggunakannya sebagai alat untuk memenuhi kebutuhan hidup saat ini yaitu menjadi tukang ojeg. Biasanya tempat mangkal utama dilakukan di pasar Darmaraja. Selain digunakan sebagai modal untuk beralih profesi, ada juga yang menggunakan modal tersebut untuk dijadikan barang sewaan. Kendaraan bermotor yang dimiliki disewakan untuk dipakai mengojeg oleh orang lain. Sehingga, pemilik kendaraan tersebut hanya tinggal mendapatkan uang setoran saja. Hal berbeda dilakukan oleh OTD masyarakat petani lainnya yang melakukan peralihan pekerjaan menjadi kuli bangunan. Alasannya, dalam memilih pekerjaan itu, dikarenakan pekerjaan tersebut tidak membutuhkan modal produktif, modal finansial, serta modal keterampilan yang banyak. Hanya butuh tenaga yang besar saja pekerjaan menjadi kuli bangunan sudah bisa dilakukan. Pekerjaan menjadi buruh bangunan dilakukan ketika ada orang yang akan membangun rumah, pembangunan jalan desa, dan pembangunan fasilitas umum lainnya. Hasil dari temuan ini senada dengan penelitian Nurhayati, A (2014) dengan judul penelitian Dampak Alih fungsi lahan Pertanian terhadap munculnya masalah sosial yang terjadi di wilayah Kabupaten Bandung. Hasil penelitian menunjukkan bahwa, "alih fungsi lahan pertanian ke non-pertanian menimbulkan masalah bagi petani kecil, dikarenakan mereka tidak memiliki keahlian lain di luar bidang pertanian. Sehingga, pekerjaan yang mereka lakukan adalah menjadi buruh bangunan, bahkan ada yang menjadi pengangguran."

Penghasilan yang tidak menentu baik dari pekerjaan menjadi petani, nelayan ikan di Waduk Jatigede, tukang ojeg dan buruh bangunan membuat sebagian dari mereka melakukan diversifikasi (menambah pendapatan) dari pekerjaan lain. Diversifikasi yang dilakukan oleh OTD masyarakat petani cukup beragam diantaranya yaitu dengan menamam sayuran, ubi- ubian atau buah-buahan di sekitar pekarangan rumah atau tanah milik pemerintah, dimana hasil dari tanaman tersebut di jual. Diversifikasi lain yang dilakukan oleh OTD masyarakat petani yaitu dengan membuka usaha opak kecil-kecilan. Perharinya opak yang dihasilkan sekitar 50 bungkus opak. Opak-opak tersebut, biasanya dijual ke pasar dengan harga Rp.5000-, per/ bungkus atau ke supermarket terdekat dengan harga Rp. 4500-, per/bungkus. Hal itu diungkapkan juga oleh Corner bahwa, beberapa bentuk strategi adaptasi aktif yang dapat dikembangkan untuk menjaga kelangsungan hidup diantaranya dapat berupa diversifikasi. Diversifikasi ini dilakukan dengan cara melakukan berbagai pekerjaan lebih banyak, meskipun hasil yang didapat sedikit (Kusnadi, 2000).

Mendorong Istri dan Anak Untuk Ikut Bekerja Pendapatan yang tidak menentu dan terbilang kecil, dari pekerjaan saat ini. Membuat OTD masyarakat petani melakukan strategi lain untuk menambah pendapatan keluarga. Berdasarkan hasil temuan penelitian, strategi yang dilakukan yaitu dengan cara mendorong istri atau anak untuk ikut bekerja mencari nafkah, agar kebutuhan keluarga dapat terpenuhi dengan baik. Seperti pendapat Nye (1982) mengatakan bahwa, "upaya untuk memenuhi kebutuhan sehari-hari sebuah keluarga yaitu bagaimana individu- individu yang ada di dalamnya harus berusaha maksimal dan bekerja sama untuk memenuhi kebutuhan rumah tangga sehingga kelangsungan hidupnya terpelihara." (Kusnadi, 2000). Pekerjaan yang dilakukan oleh istri OTD masyarakat petani diantaranya yaitu membuka warung kecil-kecilan dengan menjual sayuran dan makanan ringan di depan rumahnya, memproduksi opak, membantu menanam sayuran, ubi- ubian, serta buah-buahan untuk dijual. Hal tersebut senada dengan pendapat Andrianti bahwa, salah satu strategi yang dapat dilakukan oleh sebuah keluarga untuk mengatasi kesulitan ekonomi adalah dengan mendorong para isteri untuk ikut mencari nafkah (Kusnadi, 2000). Keterlibatan istri untuk ikut membantu mencari nafkah dikarenakan kondisi pendapatan suami yang rendah, sehingga istri memiliki peran penting dalam menopang kehidupan sosial ekonomi keluarga. Hal tersebut senada dengan apa yang dikemukakan oleh Suratiyah dkk (1994) bahwa, "faktor pendorong masuknya wanita pada kegiatan produktif terutama disebabkan oleh pendapatan suami yang kurang mencukupi."

Tidak hanya istri peran anak yang sudah mampu bekerjapun menjadi suatu strategi untuk bisa mengstabilkan kondisi sosial ekonomi keluarga. 
Pekerjaan yang dilakukan oleh anak-anak petani diantaranya yaitu ikut bekerja menjadi buruh tani, bekerja sebagai nelayan ikan di Waduk Jatigede, bekerja di pertokoan, dan ikut bekerja menjadi buruh bangunan.

\subsection{Strategi Adaptasi Sosial Ekonomi Pasif}

OTD masyarakat petani melakukan strategi pengurangan biaya pengeluaran, agar pendapatan yang diperoleh dapat mencukupi kebutuhan hidupnya. Strategi ini juga merupakan strategi yang digunakan oleh masyarakat miskin untuk bisa bertahan hidup, dengan cara meminimalisir pengeluaran uang (Kusnadi, 2000). Tindakan yang dilakukan pertama yaitu terkonsentrasikan pada pengurangan biaya makan. Strategi penghematan tersebut dilakukan dengan cara membeli bahan makanan seadanya serta mengolah bahan makanan dari hasil kebun ataupun berbagai jenis Ikan yang didapat dari Waduk Jatigede. Sehingga, biaya makan yang dikeluarkan tidak terlalu banyak. Lauk pauk yang biasa dikomsumsi yaitu seperti sayuran, tahu, tempe, serta Ikan yang di dapat dari Waduk sebagai bahan makanan sehari-hari. Strategi penghematan yang dilakukan oleh OTD masyarakat petani tersebut senada dengan Jurnal penelitian Mardiharini, M. (2005) dengan Judul "FamilyCoping Strategies in Maintaining Welfare During The Economic Crisis in Indonesia : A Case Study in Rural and Urban areas in Bogor" yang menunjukkan bahwa, strategi yang dilakukan oleh keluarga sebagai dampak dari penurunan pendapatan adalah dengan mengurangi konsumsi daging dan ikan. Sedangkan, ada peningkatan konsumsi makanan dengan bahan baku kedalai, seperti tahu dan tempe.

Pengeluaran biaya non- makanan juga, dilakukan oleh OTD masyarakat petani, dengan cara mengurangi pembelian barang- barang elektronik maupun pakaian baru. Selain itu juga, memanfaatkan kayu bakar sebagai bahan bakar memasak dibandingkan gas elfiji. Pengurangan nonmakanan juga dilakukan dengan mengurangi biaya pendidikan. Tindakan ini dilakukan dengan alasan biaya pendidikan yang tidak bisa terpenuhi oleh pendapatan saat ini. Sehingga, pengurangan biaya pendidikan di lakukan dengan mendorong anak untuk ikut bekerja mencari pendapatan bagi keluarga. Sehingga, strategi pasif merupakan suatu strategi dengan cara mengurangi biaya pengeluaran keluarga, baik itu biaya sandang, pangan, pendidikan, dan sebagainya (Suharto, E,2009).

\subsection{Strategi Adaptasi Sosial Ekonomi Jaringan Sosial}

Strategi jaringan sosial yang dilakukan oleh OTD masyarakat petani dilakukan dengan memanfaatkan akses sosial baik formal maupun informal. Strategi jaringan merupakan strategi bertahan hidup yang dilakukan dengan cara menjalin relasi, baik formal maupun dengan lingkungan sosialnya dan lingkungan kelembagaan (misalnya meminjam uang kepada tetangga, mengutang di warung atau toko, memanfaatkan program kemiskinan, meminjam uang ke rentenir atau bank dan sebagainya. (Suharto, E, 2009)

Mekipun masyarakat petani yang terkena dampak sudah melakukan berbagai macam strategi.

Namun, kenyataannya strategi tersebut terkadang tidak bisa memenuhi kebutuhan hidup yang bersifat mendesak. Akses jaringan formal yang dilakukan oleh OTD masyarakat petani dilakukan dengan cara memanfaatkan dana PNPM desa untuk dijadikan sebagai modal dalam melakukan usaha, serta memanfaatkan program kemiskinan berupa pemanfaatan raskin. Sedangkan, Akses jaringan informal dilakukan dengan meminjam uang ke tetangga/kerabat dan mengutang ke warung untuk memudahkan memenuhi kebutuhan hidup seharihari yang bersifat mendadak. Fungsi jaringan sosial adalah untuk memudahkan masyarakat memperoleh jalan alternatif ke sumber daya ekonomi yang tersedia di lingkungannya. Jaringan sosial dapat di bentuk berdasarkan basis kerabat, tetangga, pertemanan, atau campuran dari unsur-unsur tersebut. Contohnya, meminjam uang dengan tetangga, ke rentenir atau bank, mengutang di warung ataupun memanfaatkan program kemiskinan. (Sugiharjo, 2012) Jaringan sosial ini terbentuk akibat adanya interaksi sosial yang terjadi dalam masyarakat, dan dapat membantu keluarga miskin ketika membutuhkan uang secara mendesak. (Kusnadi, 2000)

Strategi adaptasi sosial ekonomi aktif, pasif dan jaringan sosial yang telah dijelaskan diatas senada dengan hasil penelitian Staszynska, M. Katarzyna, \& Zagorski, Krzysztof. (2010) dengan Judul "Strategies of Family Adaptation to Material Conditions in Polish Local Communities" yang menunjukkan bahwa, strategi adaptasi yang dilakukan oleh rumah tangga peternak di polandia dilakukan dengan cara yang berbeda-beda. Strategi adaptasi yang dilakukan diantaranya adalah dengan mendapatkan keterampilan baru untuk bekerja, berhemat, melakukan simpan pinjam, serta menjual harta benda. Hal itu dilakukan untuk menghadapi tantangan kondisi ekonomi yang memburuk. 
Tindakan strategi adaptasi sosial ekonomi yang dilakukan oleh OTD masyarakat petani, memiliki kertekaitan dengan teori structural fungsional yang dikemukakan oleh Talcott patson. Hal itu dikarenakan, OTD masyarakat petani merupakan suatu sistem sosial dengan subsistem- subsistem yang saling berkaitan dan berhubungan. Subsistemsubsistem yang ada di dalam OTD masyarakat petani mengalami perubahan diakibatkan oleh pembangunan Waduk Jatigede. Perubahan yang terjadi di dalam masyarakat, ditujukan untuk mencapai keadaan seimbang dan teratur. Masyarakat akan senantiasa berusaha untuk menstabilkan keadaan yang berubah. Salah satunya adalah mengstabilkan kebutuhan dalam bidang sosial ekonomi. Oleh karena itu, dalam mempertahankan elemen tersebut agar tetap stabil, maka OTD masyarakat petani melakukan empat prasyarat mutlak diantaranya yaitu adaptasi, goal attainment, integrasi dan latency. (Ritzer,G, dan Gouglas, J, 2011).

Adaptasi (adaptation) dilakukan oleh OTD masyarakat petani dengan cara melakukan penyesuaian diri dengan kondisi lingkungan dan sumber daya yang berubah. Penyesuaian dilakukan dengan berbagai cara dan strategi baik aktif, pasif dan jaringan sosial. Tujuan (Goal attainment) dari strategi adaptasi yang dilakukan oleh petani tidak lain adalah untuk memenuhi tujuan. Tujuan tersebut adalah untuk mencukupi kebutuhan hidup mereka dan agar mendapatkan kehidupan yang tetap stabil meskipun kondisi yang di alami mereka saat ini berbeda dengan keadaan sebelumnya. Integrasi (integration) mengacu kepada pemeliharaan subsistem dalam keluarga petani. Keluarga merupakan suatu system sosial yang terdiri dari subsistem-subsistem yang saling berkaitan dan berinterkasi satu dengan lainnya. Integrasi dalam keluarga OTD masyarakat petani melibatkan ketiga komponen AGIL lainnya. Integrasi merupakan hal yang penting agar semua keluarga mampu bekerja sama dan saling membangun dalam melakukan strategi adaptasi sosial ekonomi. Hal itu dapat terlihat dari hasil temuan penelitian, dimana dalam mencapai tujuan dalam mengstabilkan kondisi sosial ekonomi, setiap anggota keluarga baik istri ataupun anak ikut membantu dalam mengstabilkan kondisi sosial ekonomi. Pemeliharaan (Latency) strategi-strategi yang dilakukan oleh OTD masyarakat petani dipelihara dan diperbaharui sesuai dengan keadaan kondisi lingkungan yang senantiasa berubah.

\section{KESIMPULAN}

Strategi adaptasi sosial ekonomi yang dilakukan oleh OTD masyarakat petani di Blok Pasirkandaga, Desa Tarunajaya, Kec. Darmaraja, Kab. Sumedang terdiri dari 3 strategi adaptasi sosial ekonomi, diantaranya yaitu strategi aktif, strategi pasif dan strategi jaringan sosial. Strategi aktif bertujuan untuk menambah pendapatan. Tindakan strategi yang dilakukan yaitu tetap berprofesi sebagai petani, melakukan peralihan pekerjaan (Nelayan Ikan di Waduk, berjualan opak, Buruh bangunan, dan Tukang Ojeg), melakukan diversifikasi pekerjaan, melakukan migrasi serkuler, serta mendorong istri dan anak untuk ikut bekerja mencari nafkah. Bentuk strategi yang kedua yaitu Strategi pasif bertujuan untuk melakukan pengehematan biaya pengeluaran. Tindakan strategi yang dilakukan yaitu melakukan pengurangan biaya yang terkonsentrasikan pada biaya pangan, sandang, dan biaya pendidikan. Sedangkan, bentuk strategi adaptasi sosial ekonomi yang terakhir yaitu strategi jaringan sosial. Strategi jaringan sosial dilakukan dengan cara memanfaatkan akses sosial baik formal maupun informal. Tindakan strategi yang dilakukan yaitu dengan memanfaatkan Program kemiskinan, meminjam uang ke kerabat/tetanga, serta mengutang ke warung.

\section{REFERENSI}

Amila, M. dan Elly, M. (2016). Konflik Pembebasan Lahan Pembangunan Bendungan Jatigede di Desa Wado. Jurnal Sosietas, Vol 6 No. 2.

Budimansyah, D. "Fundamental Sociological Symptoms as a Source Occurance of Turbelence in Indonesian Society During The Post- Reform. "1st UPI International Conference on Sociology Education, (2015): hlm.63-66.

Harun, R. dan Ardianto, E. (2012). Komunikasi Pembangunan dan Perubahan Sosial. Jakarta : Grafindo.

Kusnadi. (2000). Nelayan Strategi Adaptasi dan Jaringan Sosial. Humaniora Utama Press. Bandung.

Mardiharini, M. (2015). Family Coping Strategies in Maintaining Welfare During the Economic Crisis in Indonesia: A Case study in rural and urban areas in Bogor. Jurnal Agro Ekonomi. Vol 23 No 1.

Miles, M. B., dan Huberman, A.M. (2012). Analisis data kualitatif: Buku sumber tentang metode-metode baru. Jakarta: Universitas Indonesia Pers.

Ratna, A. (2013). Perubahan Pekerjaan Masyarakat Sebagai Akibat Dari Bencana. Studi Kasus: Kawasan Wisata Volcano Tour Gunung 
Merapi, Desa Umbulharjo, Kecamatan

Cangkringan, Kabupaten Sleman. Jurnal Perencanaan Wilayah dan Kota, Vol. 24 No 1, hlm. 19-34.

Ritzer, G dan Gouglas J. G. (2011). Teori Sosiologi Modern. Jakarta: Prenada Media Group.

Ruhi, T. Khun. (2012). "Dam" for The Greater Common GooA Critical Cultural Analysis of the Narmada Dam Debate. International Journal of Communication 6, 194-213.

Sata, Winyoo, dkk. (2008). Environment Changes of Lampao Dam Communities inNortheast Thailand. Pakistan Journal of Social Sciences 5 (9) : 899-904.

Scones. (2001). Sustainable Rural Livelihoods A Framework For Analysis. IDS Working Paper 72. Institute of Development Studies.

Staszynska, M. Katarzyna, \& Zagorski, Krzysztof. (2010). Strategies of Family Adaptation TO Material Conditions in Polish Local Communities. International Journal of Sociology, Vol 40, No 1, Spring 2010,pp, 19-60.

Sugihardjo, dkk. (2012). Strategi Bertahan dan Strategi Adaptasi Petani Samin Terhadap Dunia Luar. Jurnal Seva. Universitas Sebelas Maret. Surakarta

Suharto, E. (2009). Kemiskinan dan Perlindungan Sosial di Indonesia. Bandung: Alfabeta 